\title{
Seasonal and spatial comparisons of phytoplankton growth and mortality rates due to microzooplankton grazing in the northern South China Sea
}

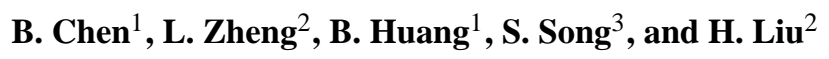 \\ ${ }^{1}$ State Key Laboratory of Marine Environmental Science and Key Laboratory of the Ministry of Education for Coastal and \\ Wetland Ecosystem, Xiamen University, Xiamen, Fujian, China \\ ${ }^{2}$ Division of Life Science, Hong Kong University of Science and Technology, Clear Water Bay, Kowloon, Hong Kong, China \\ ${ }^{3}$ Key Laboratory of Marine Ecology and Environmental Science, Institute of Oceanology, Chinese Academy of Sciences, \\ Qingdao, Shandong, China
}

Correspondence to: H. Liu (liuhb@ust.hk)

Received: 30 October 2012 - Published in Biogeosciences Discuss.: 15 November 2012

Revised: 1 April 2013 - Accepted: 11 April 2013 - Published: 29 April 2013

\begin{abstract}
We conducted a comprehensive investigation on the microzooplankton herbivory effect on phytoplankton in the northern South China Sea (SCS) using the seawater dilution technique at surface and deep chlorophyll maximum (DCM) layers on two cruises (July-August of 2009 and January of 2010). We compared vertical (surface vs. DCM), spatial (onshore vs. offshore), and seasonal (summer vs. winter) differences of phytoplankton growth $\left(\mu_{0}\right)$ and microzooplankton grazing rates $(m)$. During summer, both $\mu_{0}$ and $m$ were significantly higher at the surface than at the DCM layer, which was below the mixed layer. During winter, surface $\mu_{0}$ was significantly higher than at the DCM, while $m$ was not significantly different between the two layers, both of which were within the mixed layer. Surface $\mu_{0}$ was, on average, significantly higher in summer than in winter, while average surface $m$ was not different between the two seasons. There were no cross-shelf gradients of $\mu_{0}$ in summer or winter surface waters. In surface waters, $\mu_{0}$ was not correlated with ambient nitrate concentrations, and the effect of nutrient enrichment on phytoplankton growth was not pronounced. There was a decreasing trend of $m$ from shelf to basin surface waters in summer, but not in winter. Microzooplankton grazing effect on phytoplankton $\left(m / \mu_{0}\right)$ was relatively small in the summer basin waters, indicating a decoupling of microzooplankton grazing and phytoplankton growth at this time. On average, microzooplankton grazed $73 \%$ and $65 \%$ of the daily primary production in summer and winter, respectively.
\end{abstract}

\section{Introduction}

Microzooplankton $(<200 \mu \mathrm{m}$; including nanoflagellates, ciliates, dinoflagellates, sarcodines, and small metazoans) are the major grazers of phytoplankton, accounting for the loss of $\sim 60-80 \%$ of daily primary production in the sea (Calbet and Landry, 2004). Owing to their fast reproduction rates (Banse, 1982), microzooplankton grazing is able to respond quickly to the increased phytoplankton growth rate upon nutrient enrichment (Landry et al., 2000). Nutrients excreted by microzooplankton are particularly important for maintaining low phytoplankton biomass but relatively high growth rates of phytoplankton in some high-nitrate, low-chlorophyll (HNLC) regions (Frost and Franzen, 1992; Landry et al., 1997; Strom et al., 2000).

The ratio of the microzooplankton grazing rate to the phytoplankton growth rate $\left(m / \mu_{0}\right)$, which describes how much of the primary production is consumed by microzooplankton, is related with the efficiency of the biological pump, as the part of primary production that is not consumed by microzooplankton is either consumed by mesozooplankton or directly sinks out of the euphotic zone (Landry et al., 1995, 1998). A high $m / \mu_{0}$ ratio would indicate an active microbial food web and that the trophic flow through the diatom-copepod food chain is comparatively weak. The $m / \mu_{0}$ ratio is often reasonably believed to be greater in oligotrophic waters where phytoplankton are dominated by small-sized species which are more edible 
for microzooplankton, whereas in eutrophic waters, mesozooplankton grazing and sinking should be more important for the loss of phytoplankton production, contributing to a greater efficiency of carbon export than in oligotrophic waters (Laws, 2003). Using a global dataset, Calbet and Landry (2004) showed that the average $m / \mu_{0}$ decreased from $70 \%$ in oligotrophic oceanic waters to about $60 \%$ in estuarine and coastal waters, although they did not find a significant correlation between $m / \mu_{0}$ and chlorophyll concentration in the pooled dataset of all dilution experiments. Liu et al. (2002a) noted that, as some diatoms might be too large for microzooplankton to ingest, microzooplankton only consumed roughly one third of daily primary production in the Bering Sea where diatoms dominated. Huang et al. (2011) also observed a higher $m / \mu_{0}$ ratio in non-upwelling areas than in upwelling areas dominated by diatoms. Strom et al. (2007) found that microzooplankton grazing rates for large phytoplankton $(>20 \mu \mathrm{m})$ were generally lower than those for small phytoplankton $(<20 \mu \mathrm{m})$ in the coastal Gulf of Alaska. One of our previous studies (Chen and Liu, 2010) also demonstrated that $m / \mu_{0}$ was significantly negatively correlated with phytoplankton average size.

Temperature is another important factor that may decouple phytoplankton growth and microzooplankton grazing rates. Rose and Caron (2007) showed that maximal zooplankton growth rates increase faster with temperature than maximal phytoplankton growth rates. Quantitatively, the slope of $\ln$ phytoplankton growth rate versus temperature is 0.06 $\left(Q_{10}=1.82\right)$ and the slope of $\ln$ herbivorous microzooplankton growth rate versus temperature is $0.10\left(Q_{10}=2.72\right)$. The implication is that, other things being equal, $m / \mu_{0}$ should increase with temperature with a $Q_{10}$ of 1.49 .

Recently, Landry et al. (2011) pointed out the potential effect of light to decouple $m$ from $\mu_{0}$. From the surface of the ocean to the bottom of the euphotic zone, light intensity decreases exponentially, which causes a substantial reduction of $\mu_{0}$, while $m$ may not be affected as much as $\mu_{0}$. As such, other things being equal, microzooplankton should remove a greater proportion of primary production at depth compared with the light-saturated surface waters.

The South China Sea (SCS) is the second largest marginal sea in the world. There are relatively few data on microzooplankton grazing rates in this area compared with primary production data (Liu et al., 2002b; Chen and Chen, 2006). In the northern SCS, the most salient physical factor is the seasonal reversal monsoons. During summer, the southwest monsoon induces clockwise water current circulation in the northern SCS and coastal upwelling over the widened continental shelf (Wong et al., 2007; Gan et al., 2009), while the upper ocean layer forms a large-scale cyclonic circulation under the influence of the northeast monsoon in winter and the nutrient-rich East China Sea coastal water can flow into the northern SCS through the Taiwan Strait. In offshore waters of SCS, phytoplankton biomass, primary production, and new production peak during wintertime when the mixed layer deepens and nutrients are entrained into the euphotic zone (Liu et al., 2002b; Ning et al., 2004; Chen and Chen, 2006). In summer, the enhanced Pearl River discharge may also induce higher phytoplankton biomass and primary production in the plume area.

Our objective was to investigate how the microzooplankton grazing effect on phytoplankton responds to seasonal monsoons at different localities in the northern SCS. We conducted dilution experiments (Landry and Hassett, 1982) on two cruises, which covered a large area of the northern SCS in summer and winter. Based on the above arguments, we attempted to test three hypotheses listed below:

1. The $m / \mu_{0}$ ratios should be lower in surface waters than in deeper waters due to differential light effects on $\mu_{0}$ and $m$.

2. As nutrient supply rates should be lower and the waters should be more oligotrophic in summer than in winter, the average phytoplankton growth rates $\left(\mu_{0}\right)$ should be lower in summer than in winter. The $m / \mu_{0}$ ratios should, on average, be higher in summer when phytoplankton cells are smaller and temperature is higher.

3. Along the onshore-offshore gradient where nutrient supply rates decrease, we should also observe a decreasing trend of phytoplankton growth rates and an increasing trend of $m / \mu_{0}$ ratios.

\section{Material and methods}

Dilution experiments were conducted at a total of 46 stations during two cruises, one during the summer (18 July to $16 \mathrm{Au}-$ gust 2009; 22 stations) and the other in winter (6 to 30 January 2010; 24 stations) in the northern SCS (Fig. 1). At each station, seawater samples were collected from two depths (1 $\mathrm{m}$ and the DCM layer) using acid-washed normal Niskin bottles attached to a CTD rosette system. During the winter, a DCM layer did not exist at many stations (Table S1, S2) and the so-called "DCM layer" was determined as roughly $5 \%$ of surface irradiance. All incubation bottles, tubing and carboys were washed with $10 \% \mathrm{HCl}$ and rinsed thoroughly with distilled water and ambient seawater before each experiment. Measured amounts of particle-free water, prepared by gravity filtering the seawater through a $0.2 \mu \mathrm{m}$ filter capsule (Pall Corporation), were first added to $1.2 \mathrm{~L}$ polycarbonate bottles, and the bottles were then gently filled with whole seawater to capacity. To minimize the damage to delicate microzooplankton cells, we did not use $200 \mu \mathrm{m}$ meshes to preclude the mesozooplankton as the mesozooplankton grazing effect on phytoplankton was negligible (M. Chen, in revision). The filter capsules were soaked in $10 \% \mathrm{HCl}$ for more than $2 \mathrm{~h}$ before the first use and were washed with diluted acid, distilled water and ambient seawater between each experiment to eliminate possible toxins associated with 


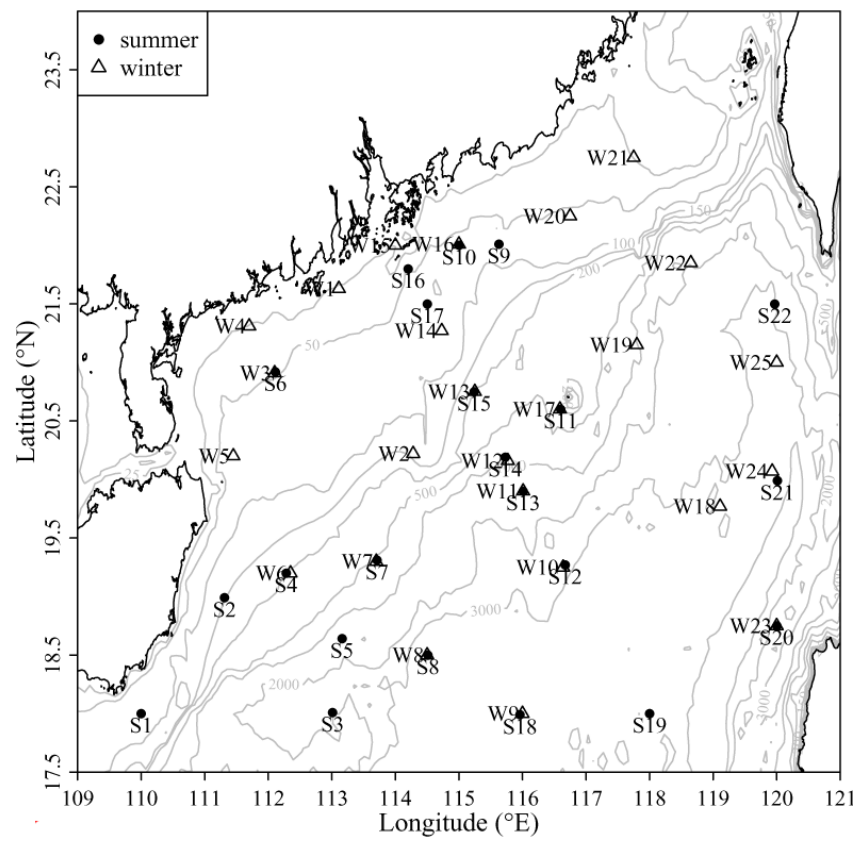

Fig. 1. Experimental locations.

the capsules (Landry et al., 1995). Five dilution treatments of $15,27,50,73$ and $100 \%$ natural seawater were prepared. All five bottles were enriched with inorganic nutrients (final concentrations of $0.5 \mu \mathrm{mol} \mathrm{L}^{-1} \mathrm{NH}_{4} \mathrm{Cl}, 0.03 \mu \mathrm{mol} \mathrm{L}^{-1}$ $\mathrm{KH}_{2} \mathrm{PO}_{4}, 1 \mathrm{nmol} \mathrm{L}-1 \mathrm{FeCl}_{3}$, and $0.1 \mathrm{nmol} \mathrm{L}^{-1} \mathrm{MnCl}_{2}$ ) to promote constant phytoplankton growth. Another two bottles filled with unfiltered seawater without nutrient addition served as no nutrient controls. Two additional bottles filled with unfiltered seawater were sacrificed for initial samples for chlorophyll $a(\mathrm{Chl} a)$ and flow cytometric (FCM) analyses. All of the bottles were tightly capped and incubated for $24 \mathrm{~h}$ in a deck incubator cooled by running surface seawater and covered with neutral screens to simulate in situ light environment. Incubations were typically initiated within $1 \mathrm{~h}$ after water collection. After incubation, samples were taken from each bottle for Chl $a$ and FCM analyses.

For Chl $a$ analyses, $300 \mathrm{~mL}$ to $1.2 \mathrm{~L}$ seawater samples were filtered onto $\mathrm{GF} / \mathrm{F}$ glass fiber filters under low vacuum. The filters were extracted in $90 \%$ acetone at $4{ }^{\circ} \mathrm{C}$ in the dark for $24 \mathrm{~h}$ and the $\mathrm{Chl} a$ concentrations were measured by the non-acidification method (Welschmeyer, 1994) on a Turner Designs fluorometer (Model No. Trilogy 040).

FCM samples were fixed with $0.5 \%$ buffered paraformadehyde and frozen at $-80^{\circ} \mathrm{C}$ (Vaulot et al., 1989). Cell abundances of picophytoplankton were enumerated using a Becton Dickinson FACSCalibur cytometer, with different populations distinguished based on side-scattering (SS) and orange and red fluorescence (Olson et al., 1993). Yellowgreen fluorescent beads $(1 \mu \mathrm{m}$, Polysciences) were added to the samples as an internal standard. For counting heterotrophic nanoflagellates, the samples were stained with
$0.02 \%$ SYBR Green I (Molecular Probes) in the dark under the presence of $30 \mathrm{mmol} \mathrm{L}^{-1}$ potassium citrate at $37^{\circ}$ for $1 \mathrm{~h}$ before analysis (Zubkov et al., 2006). The exact flow rate was calibrated by weighing a tube filled with distilled water before and after running for certain time intervals and the flow rate was estimated as the slope of a linear regression curve between elapsed time and weight differences (Li and Dickie, 2001).

For collecting and counting ciliates and dinoflagellates, water samples were gently siphoned from Niskin bottles into a $500 \mathrm{~mL}$ plastic amber bottle which was filled with acidic Lugol's solution (final concentration $5 \%$ ) beforehand. The preserved samples were stored in the dark at room temperature until analysis. Upon return to the lab, the samples were observed with an inverted microscopy (Leica Dmirb). Cell length and width were sized using the software Simple PCI6. Cellular carbon content of ciliates was calculated from biovolumes using a conversion factor

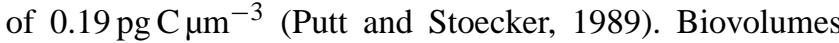
of dinoflagellates were converted to cell carbon using the equation: pg Ceell ${ }^{-1}=0.76 \times$ volume $\left(\mu \mathrm{m}^{3}\right)^{0.819}$, according to Mender-Deuer and Lessard (2000). Only heterotrophic dinoflagellates were included in the biomass of microzooplankton.

Assuming an exponential growth model, we calculated the net growth rate $\left(k_{i}\right)$ of phytoplankton in each dilution treatment according to the formula $k_{i}=\ln \left[C_{i} /\left(D_{i} \times \mathrm{C}_{o}\right)\right]$, where $C_{i}$ is the Chl $a$ concentration in the $i$ th treatment bottle at $24 \mathrm{~h}, D_{i}$ is the dilution factor (proportion of unfiltered seawater) of the $i$ th treatment, and $C_{o}$ is the initial Chl $a$ concentration. Estimates of phytoplankton growth rate with nutrient enrichment $\left(\mu_{\mathrm{n}}\right)$ and mortality rate $(m)$ were derived from Model I linear regressions of net growth rate against dilution factor (Landry and Hassett, 1982). In situ estimates of phytoplankton instantaneous growth rate $\left(\mu_{0}\right)$ were computed as the sum of $m$ and net growth rate in control bottles without added nutrients. For three cases of positive slope of the linear regression (negative grazing rates, but not significantly different from zero; Tables S1, S2), we determined $m$ to be zero and $\mu_{\mathrm{n}}$ to be the average value of the net growth rates of all five dilution treatments with nutrient enrichment (Murrell et al., 2002).

We used FCM-derived estimates of cellular biovolume and fluorescence to correct $\mathrm{Chl} a$ estimates of phytoplankton growth rate for pigment photoacclimation. For each experiment, the ratios $(R)$ of cellular red fluorescence to biovolume were calculated for initial and final FCM samples. Corrected phytoplankton growth rates $\left(\mu_{0}^{\prime}\right.$ and $\left.\mu_{\mathrm{n}}^{\prime}\right)$ were calculated as $\mu^{\prime}=\mu-\ln \left(\mathrm{R}_{\mathrm{f}} / R_{\mathrm{i}}\right)$, where $R_{\mathrm{i}}$ and $R_{\mathrm{f}}$ are the initial and final $R$ estimates (Landry et al., 2003; Chen et al., 2009b). $m$ was not affected by changes in cellular pigment contents.

Corresponding seawater temperature, salinity, pressure, nutrient, and Chl a concentrations were also measured. Temperature, salinity, and pressure were determined by 
conductivity-temperature-depth (CTD) probes. Mixed layer depth (MLD) was defined as the first depth where temperature was $0.2^{\circ} \mathrm{C}$ lower than at surface $(5 \mathrm{~m})$ (Irwin and Finkel, 2008; Steinhoff et al., 2010). Nutrients were measured following standard methods (Parsons et al., 1984).

\section{Results}

For identifying spatial patterns, we classify the stations into three groups according to bathymetry: shelf (bottom depth $\leq 100 \mathrm{~m}$ ), slope $(100 \mathrm{~m}<$ bottom depth $\leq 2000 \mathrm{~m})$, and basin (bottom depth $>2000 \mathrm{~m}$ ). Note that although this crude approach neglects the very dynamics of water masses, it provides a straightforward way to show the major cross-shelf gradients.

\subsection{Temperature, nutrients, and mixed layer depth (MLD)}

The background information of physical and chemical parameters is given in Table 1, with the details in the supplemental data of Tables S1 and S2. Most summer stations were warm, oligotrophic, and stratified, while winter stations were relatively cool, mesotrophic, and well mixed. There were no evident cross-shelf gradients of temperature and nutrient concentration in summer surface waters; while in winter, shelf surface waters were cooler and richer in nutrients than slope and basin waters. The depth of the DCM layer was usually below MLD in summer but shallower than MLD in winter.

\subsection{Chl $a$ and microzooplankton biomass $\left(B_{z}\right)$}

In summer, surface Chl $a$ concentrations (mean $=0.12$ and $0.15 \mu \mathrm{g} \mathrm{L}^{-1}$, for slope and basin waters, respectively) were significantly lower than those at DCM layers (mean $=0.62$ and $0.57 \mu \mathrm{g} \mathrm{L}^{-1}$, respectively) in slope and basin waters (paired Wilcoxon tests, $p<0.05$ ); this vertical difference was not observed in winter (Fig. 2). In shelf waters, Chl $a$ concentrations were insignificantly different between surface and DCM waters in both summer and winter (paired Wilcoxon tests, $p>0.05$; Fig. 2a,b). Comparing seasonal differences, in slope and basin waters, surface Chl $a$ concentrations were significantly lower in summer than in winter (mean $=0.55$ and $0.61 \mu \mathrm{g} \mathrm{L}{ }^{-1}$, for winter slope and basin waters, respectively; Wilcoxon tests, $p<0.01$ ), while surface $\mathrm{Chl} a$ concentrations were insignificantly different between summer and winter in shelf waters $(p>0.05)$. In both seasons, spatially, there is a decreasing trend of both surface and DCM Chl $a$ concentrations from shelf to deeper stations (Fig. 2).

In spite of the large differences of $\mathrm{Chl} a$ concentrations between surface and DCM in summer slope and basin waters, $B_{z}$ did not differ significantly between the two depths in summer $(p>0.05$; Fig. 3$)$. Within each region, $B_{z}$ did
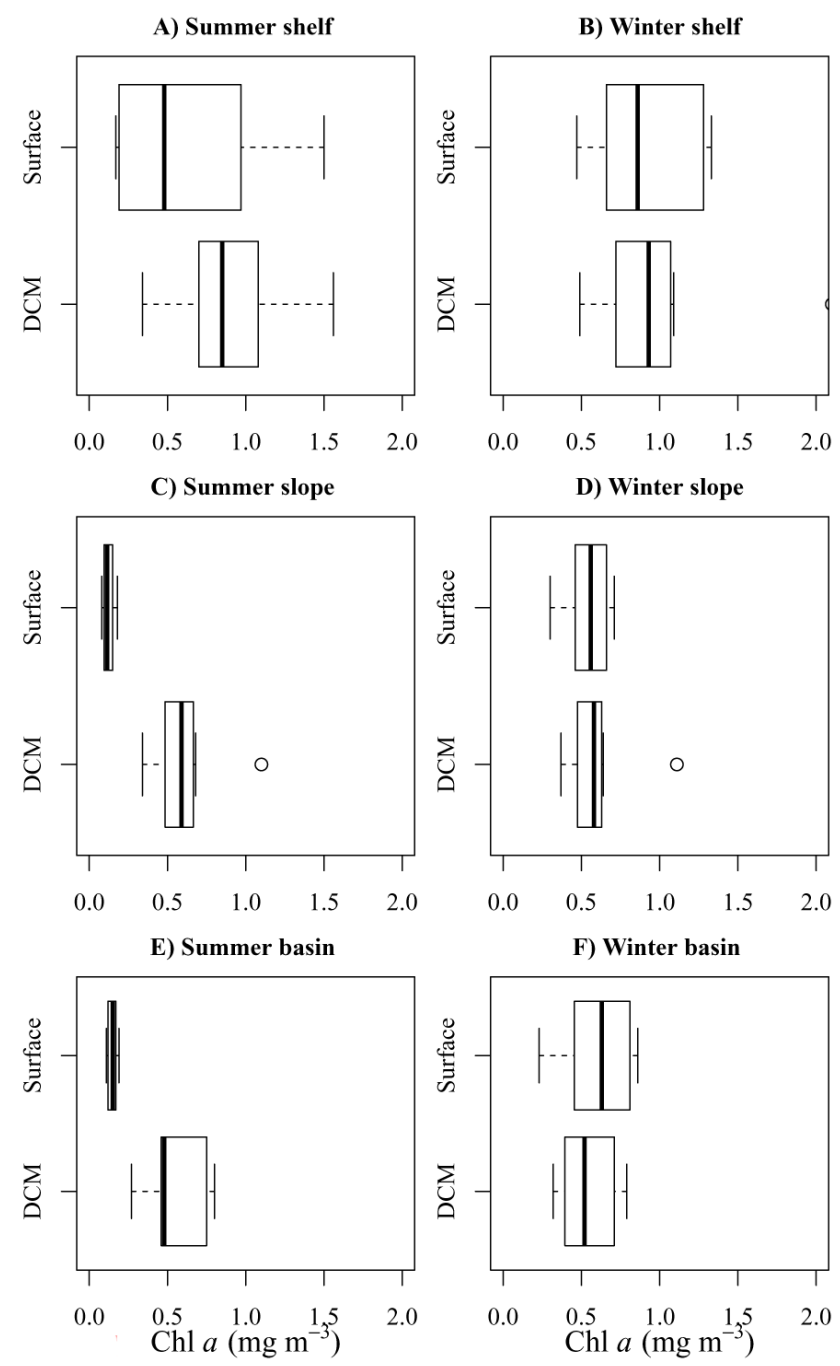

Fig. 2. Box plots of Chl $a\left(\mathrm{mg} \mathrm{m}^{-3}\right)$ in surface and DCM waters. The line through the middle of the box shows the median. The outer edges of the box correspond to the 25th and 75th percentiles, and the "whiskers" to the 10th and 90th percentiles. The dots represent extreme values.

not differ significantly between summer and winter either $(p>0.05)$. There is a decreasing trend of surface $B_{z}$ from shelf to basin waters in summer $(t$ test, $p<0.01)$, but not in winter (Fig. 3). During summer, $B_{z}$ was positively correlated with Chl $a$ in surface waters (Spearman $r=0.46, p<0.05$ ), but not in DCM waters $(p>0.05)$. There was no such positive correlation in the winter. The ratio of $B_{z}$ over Chl $a$ was significantly greater in surface waters than in DCM in the summer (paired Wilcoxon test, $\mathrm{df}=15, p<0.001$ ), but not in winter. In surface waters, the ratio of $B_{z}: \mathrm{Chl} a$ was also significantly higher in the summer than in the winter (Wilcoxon test, $p<0.001$ ), which might be caused by higher carbon-to-chlorophyll ratios of phytoplankton and/or higher microzooplankton-to-phytoplankton biomass ratios in summer. 
Table 1. Background information on physical and chemical parameters of experimental stations. The stations are grouped based on bathymetry (see text for details). SST: sea surface temperature $\left({ }^{\circ} \mathrm{C}\right)$. $\left[\mathrm{NO}_{3}\right]$ : nitrate concentration $\left(\mu \mathrm{mol} \mathrm{L}{ }^{-1}\right)$. MLD: mixed layer depth (m). DCM: depth of deep chlorophyll maximum $(\mathrm{m})$. The numbers without parentheses are median values and the numbers in parentheses indicate the minimum to maximum of the variables.

\begin{tabular}{|c|c|c|c|c|c|c|c|c|}
\hline & Region & No. of stations & SST & Surface $\left[\mathrm{NO}_{3}\right]$ & MLD & DCM & DCM temperature & $\mathrm{DCM}\left[\mathrm{NO}_{3}\right]$ \\
\hline \multirow[t]{3}{*}{ Summer } & Shelf & 6 & $\begin{array}{c}29.1 \\
(28.0-30.1)\end{array}$ & $\begin{array}{c}0.14 \\
(0.08-0.16)\end{array}$ & $\begin{array}{c}11 \\
(8-20)\end{array}$ & $\begin{array}{c}50 \\
(25-50)\end{array}$ & $\begin{array}{c}23.8 \\
(22.6-24.4)\end{array}$ & $\begin{array}{c}0.85 \\
(0.16-2.17)\end{array}$ \\
\hline & Slope & 8 & $\begin{array}{c}29.7 \\
(29.3-29.7)\end{array}$ & $\begin{array}{c}0.11 \\
(0.04-0.14)\end{array}$ & $\begin{array}{c}23 \\
(4-37)\end{array}$ & $\begin{array}{c}52 \\
(50-75)\end{array}$ & $\begin{array}{c}23.8 \\
(22.0-26.2)\end{array}$ & $\begin{array}{c}0.88 \\
(0.06-4.55)\end{array}$ \\
\hline & Basin & 8 & $\begin{array}{c}29.4 \\
(28.6-29.8)\end{array}$ & $\begin{array}{c}0.10 \\
(0.08-0.15)\end{array}$ & $\begin{array}{c}22 \\
(3-31)\end{array}$ & $\begin{array}{c}70 \\
(50-75)\end{array}$ & $\begin{array}{c}24.2 \\
(23-28.8)\end{array}$ & $\begin{array}{c}1.59 \\
(0.14-8.59)\end{array}$ \\
\hline \multirow[t]{3}{*}{ Winter } & Shelf & 9 & $\begin{array}{c}21.3 \\
(16.8-22.7)\end{array}$ & $\begin{array}{c}0.90 \\
(0.14-11.7)\end{array}$ & $\begin{array}{c}42 \\
(28-82)\end{array}$ & $\begin{array}{c}20 \\
(15-25)\end{array}$ & $\begin{array}{c}21.3 \\
(16.8-22.7)\end{array}$ & $\begin{array}{c}0.89 \\
(0.53-9.98)\end{array}$ \\
\hline & Slope & 9 & $\begin{array}{c}23.9 \\
(22.7-24.6)\end{array}$ & $\begin{array}{c}0.23 \\
(0.10-0.62)\end{array}$ & $\begin{array}{c}66 \\
(21-155)\end{array}$ & $\begin{array}{c}50 \\
(30-75)\end{array}$ & $\begin{array}{c}23.7 \\
(22.1-24.5)\end{array}$ & $\begin{array}{c}0.31 \\
(0-1.75)\end{array}$ \\
\hline & Basin & 7 & $\begin{array}{c}24.5 \\
(23.8-25.9)\end{array}$ & $\begin{array}{c}0.25 \\
(0.10-1.21)\end{array}$ & $\begin{array}{c}54 \\
(26-68)\end{array}$ & $\begin{array}{c}50 \\
(50-75)\end{array}$ & $\begin{array}{c}24 \\
(19-24.5)\end{array}$ & $\begin{array}{c}1.3 \\
(0.28-9.4)\end{array}$ \\
\hline
\end{tabular}

\subsection{Phytoplankton growth and mortality rates due to microzooplankton grazing}

The detailed results for each experiment are shown in data appendices Tables S1 and S2. In both seasons, when pooling the data from shelf, slope, and basin areas together, surface $\mu_{0}$ (mean $\pm \mathrm{sd}$ : $0.89 \pm 0.45 \mathrm{~d}^{-1}$ and $0.61 \pm 0.32 \mathrm{~d}^{-1}$, for summer and winter, respectively) were significantly higher than that in DCM layers (mean \pm sd: $0.29 \pm 0.34 \mathrm{~d}^{-1}$ and $0.45 \pm 0.21 \mathrm{~d}^{-1}$, for summer and winter, respectively) (paired Wilcoxon tests, $p<0.01$ ) (Fig. 4). Phytoplankton mortality rates due to microzooplankton grazing $(\mathrm{m})$ averaged $0.49 \pm 0.47 \mathrm{~d}^{-1}$ and $0.35 \pm 0.21 \mathrm{~d}^{-1}$ (mean $\pm \mathrm{sd}$ ) for summer and winter, respectively, in surface waters and averaged $0.21 \pm 0.13 \mathrm{~d}^{-1}$ and $0.34 \pm 0.11 \mathrm{~d}^{-1}$ (mean $\pm \mathrm{sd}$ ) for summer and winter, respectively, in DCM waters. The $m$ estimates were significantly higher in surface than in DCM layers (Wilcoxon tests, $p<0.05$ ) in summer shelf and slope waters, but not so in basin waters or during winter $(p>0.05$; Fig. 5). In the pooled dataset of shelf, slope, and basin waters, the percentage of daily primary production consumed by microzooplankton $\left(\mathrm{m} / \mu_{0}\right)$ did not differ significantly between surface (mean \pm sd: $62 \pm 44 \%$ ) and DCM layers (mean \pm sd: $86 \pm 89 \%$ ) in summer, but was significantly higher at DCM (mean \pm sd: $102 \pm 110 \%$ ) than in surface waters (mean \pm sd: $58 \pm 33 \%$ ) in winter (paired Wilcoxon tests, $p<0.05$; Fig. 6).

The seasonal difference is that, on average, surface $\mu_{0}$ were significantly higher in summer than in winter in shelf waters (Wilcoxon test, $p<0.05$ ), but were similar in slope and basin waters (Fig. 4). No differences of surface $m$ could be found between summer and winter, while $m$ values at DCM were significantly lower in summer than in winter (Wilcoxon test, $p<0.01$ ).
The high growth rate of phytoplankton in the summer surface waters was consistent with the relatively high nutrient limitation index $\left(\mu_{0} / \mu_{\mathrm{n}}\right)($ median $=85.3 \%$ and $94.4 \%$ in summer and winter, respectively; Fig. 7). Surface nitrate concentration was not correlated with $\mu_{0}$ or $\mu_{0} / \mu_{\mathrm{n}}$ in surface waters in either season $(p>0.05)$.

The relatively high $\mu_{0}$ values in the summer surface waters were partially related with high temperature given the positive correlation between temperature and $\mu_{0}$ in the pooled dataset (Spearman $r_{\mathrm{s}}=0.30, p<0.05$; Fig. 8a). The estimates of $\mu_{0}$ were not correlated with Chl $a$ concentrations in either season ( $p>0.05$; Fig. 8b). The surface $m$ estimates were positively correlated with temperature during the winter after excluding a lowest value $\left(r_{\mathrm{s}}=0.46, p<0.05\right.$; Fig. $\left.8 \mathrm{c}\right)$, but were positively correlated with $B_{z}\left(r_{\mathrm{s}}=0.49, p<0.05\right)$ and Chl $a\left(r_{\mathrm{s}}=0.53, p<0.05\right.$; Fig. $\left.8 \mathrm{~d}\right)$ concentrations in summer. The ratios of $m / \mu_{0}$ were not correlated with temperature or Chl $a$ concentrations in either season (Fig. 8e,f).

\section{Discussion}

\subsection{Comparisons of rate estimates with previous studies in the northern SCS and in other areas with similar latitude}

There are not many studies on microzooplankton grazing in the northern SCS and most of them are concentrated in surface waters. One impression arising from browsing the available data is that the rate estimates are quite variable corresponding to the complex coastal hydrographic dynamics such as upwelling, typhoons, coastal current and river plume (Table 2). For example, Huang et al. (2011) reported an average phytoplankton growth rate of $1.02 \pm 0.27 \mathrm{~d}^{-1}$ and an average microzooplankton grazing rate of $0.85 \pm 0.37 \mathrm{~d}^{-1}$ in 
A) Summer shelf

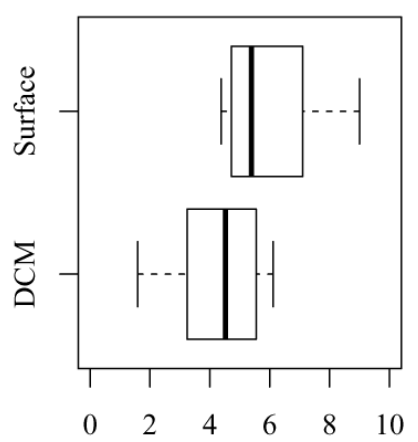

C) Summer slope

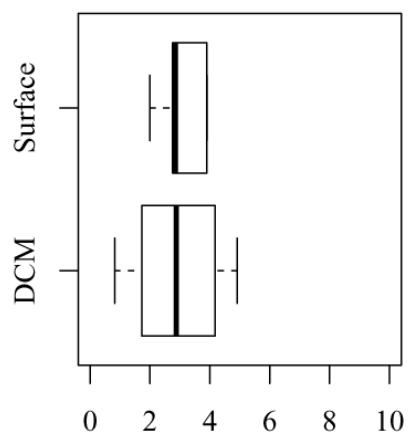

E) Summer basin

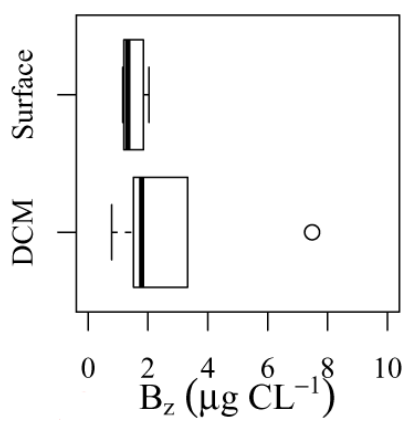

B) Winter shelf

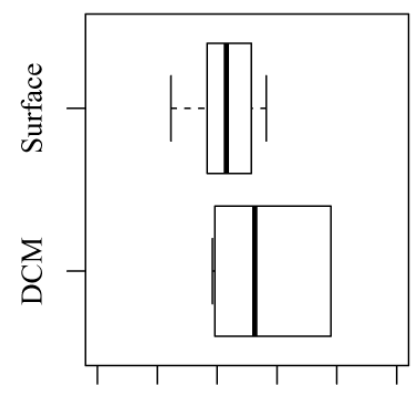

$\begin{array}{llllll}0 & 2 & 4 & 6 & 8 & 10\end{array}$

D) Winter slope

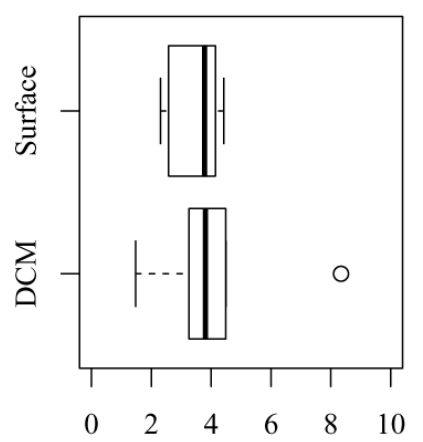

F) Winter basin

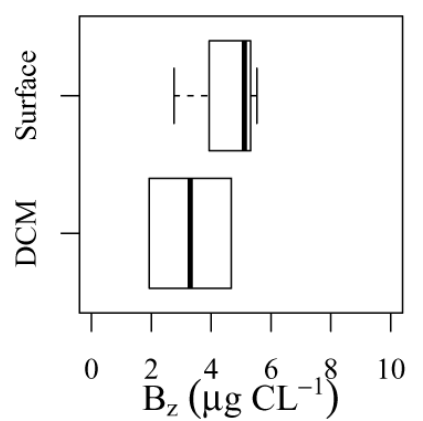

Fig. 3. Box plots of microzooplankton biomass $\left(B_{z}\right)$.

upwelling regions of northeastern SCS during summertime, while in non-upwelling regions, the rate estimates lowered to $0.51 \pm 0.05 \mathrm{~d}^{-1}$ and $0.50 \pm 0.17 \mathrm{~d}^{-1}$ for phytoplankton growth and microzooplankton grazing, respectively. Zhou et al. (2011) also estimated phytoplankton growth and microzooplankton grazing rates in the northeastern SCS after passage of a typhoon. It seemed that they had sampled a post-bloom phase as many of their experiments demonstrated negative phytoplankton growth rates and the microzooplankton grazing rates were highly variable. Chen et al. (2009a) and Lie and Wong (2010) have reported high phytoplankton growth $\left(>1.5 \mathrm{~d}^{-1}\right)$ and microzooplankton grazing rates $\left(>1.0 \mathrm{~d}^{-1}\right)$ in Hong Kong near-shore waters during summertime, which are more eutrophic than most of our sampling stations. Su et al. (2007) also reported high phytoplankton growth and microzooplankton grazing rates at a coastal sta-

A) Summer shelf

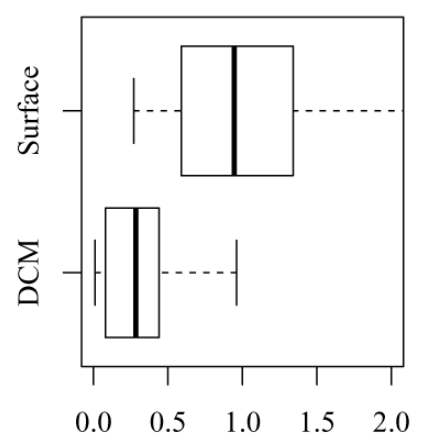

C) Summer slope

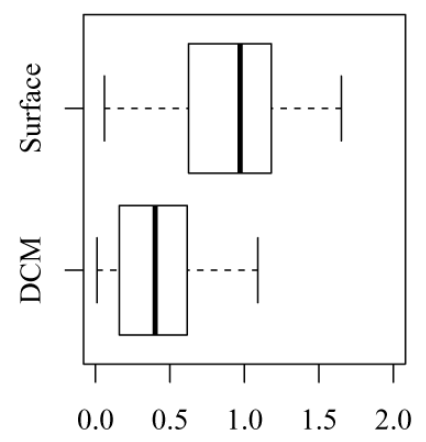

E) Summer basin

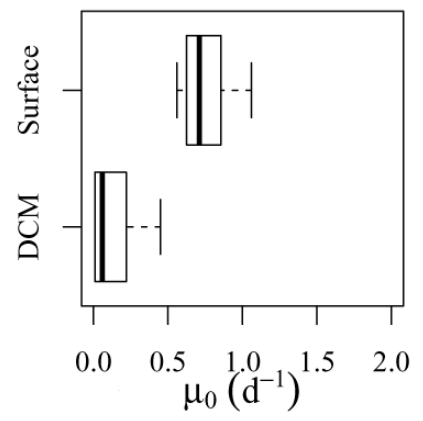

B) Winter shelf

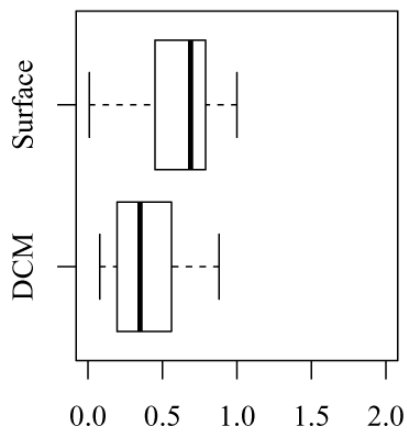

D) Winter slope

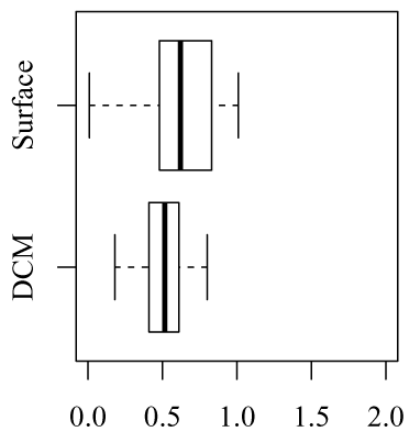

F) Winter basin

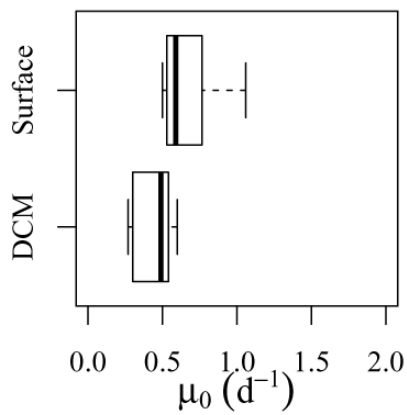

Fig. 4. Box plots of phytoplankton instantaneous growth rate $\left(\mu_{0}\right)$.

tion near Hong Kong. Their estimates $\left(\sim 0.1 \mathrm{~d}^{-1}\right)$ at $75 \mathrm{~m}$ of 4 other basin stations are similar to our estimates at DCM layers of basin waters in summer.

Globally, although hundreds of papers have been published estimating microzooplankton grazing rates using the dilution technique (Calbet and Landry, 2004; Chen et al., $2012)$, there are relatively few studies at similar latitudes $\left(\sim 20^{\circ} \mathrm{N}\right)$ in open ocean waters. The $\mu_{0}$ and $m$ values estimated by Landry et al. (1998) in the Arabian Sea, which is at similar latitudes as ours, are similar to our estimates both in summer (mean growth rate $=0.85 \mathrm{~d}^{-1}$ and mean grazing rate $=0.68 \mathrm{~d}^{-1}$ at surface) and winter (mean growth rate $=0.62 \mathrm{~d}^{-1}$ and mean grazing rate $=0.65 \mathrm{~d}^{-1}$ at surface $)$ (see their Fig. 3). Their rate estimates at low light (5\% surface irradiance) were also similar to ours. Also in the Arabian Sea, the estimates of Edwards et al. (1999) were slightly 
Table 2. A list of studies with phytoplankton growth rate $\left(\mu_{0}, \mathrm{~d}^{-1}\right)$ and microzooplankton grazing rate $\left(m, \mathrm{~d}^{-1}\right)$ data (mean \pm sd) in the SCS using the dilution technique.

\begin{tabular}{|c|c|c|c|c|}
\hline Reference & Time & Location & $\mu_{0}$ & $m$ \\
\hline Su et al. (2007) & Sep-Oct & SCS & $\begin{array}{l}10 \mathrm{~m} \text { (near Hong Kong): } 2.13 \\
75 \mathrm{~m}: 0.07 \pm 0.05\end{array}$ & $\begin{array}{l}10 \mathrm{~m} \text { (near Hong Kong): } 1.06 \\
75 \mathrm{~m}: 0.05 \pm 0.05\end{array}$ \\
\hline Chen et al. (2009a) & Whole year & $\begin{array}{l}\text { Hong Kong coastal } \\
\text { surface waters }\end{array}$ & $\begin{array}{l}\text { Estuarine water: } 1.34 \pm 0.73 \\
\text { Oceanic water: } 0.92 \pm 0.51\end{array}$ & $\begin{array}{l}\text { Estuarine water: } 0.73 \pm 0.41 \\
\text { Oceanic water: } 0.57 \pm 0.54\end{array}$ \\
\hline Lie and Wong (2010) & Mar-Jan & $\begin{array}{l}\text { Hong Kong eastern } \\
\text { coastal waters }\end{array}$ & $0.88 \pm 0.89$ & $0.79 \pm 0.57$ \\
\hline Huang et al. (2011) & Summer (Jun-Aug) & $\begin{array}{l}\text { Southern Taiwan Strait } \\
\text { surface waters }\end{array}$ & $\begin{array}{l}\text { Upwelling area: } 1.02 \pm 0.27 \\
\text { Non-upwelling area: } 0.51 \pm 0.05\end{array}$ & $\begin{array}{l}\text { Upwelling area: } 0.85 \pm 0.37 \\
\text { Non-upwelling area: } 0.50 \pm 0.17\end{array}$ \\
\hline Zhou et al. (2011) & Summer (Jun-Jul) & $\begin{array}{l}\text { Northern SCS shelf } \\
\text { surface waters }\end{array}$ & $0.16 \pm 1.00$ & $1.17 \pm 0.56$ \\
\hline This study & Aug and Jan & Northern SCS & $\begin{array}{l}\text { Summer surface: } 0.89 \pm 0.45 \\
\text { Winter surface: } 0.61 \pm 0.32 \\
\text { Summer DCM: } 0.29 \pm 0.34 \\
\text { Winter DCM: } 0.45 \pm 0.21\end{array}$ & $\begin{array}{l}\text { Summer surface: } 0.49 \pm 0.47 \\
\text { Winter surface: } 0.35 \pm 0.21 \\
\text { Summer DCM: } 0.21 \pm 0.13 \\
\text { Winter DCM: } 0.34 \pm 0.11\end{array}$ \\
\hline
\end{tabular}

lower (growth rate ranged from $0.25 \mathrm{~d}^{-1}$ to $1.77 \mathrm{~d}^{-1}$ and grazing rate from $0.15 \mathrm{~d}^{-1}$ to $0.68 \mathrm{~d}^{-1}$ ) but still lied within the normal range. For the Pacific and Atlantic Ocean at similar latitudes, we are not aware of any comprehensive studies on microzooplankton herbivory.

It is still difficult to reliably predict $m$, not even mentioning $m / \mu_{0}$, using remotely sensed variables such as temperature and Chl $a$ concentrations. Using a global dataset we compiled previously (Chen et al., 2012), we found that temperature and $\mathrm{Chl} a$ concentrations together explained less than $20 \%$ of total variance of $m$ using the flexible generalized additive modeling (the authors' unpublished data). Predator-prey interactions within the plankton consortium are complex (Peters, 1994; Poulin and Franks, 2010), and it remains to be investigated whether we should develop a better model or whether it is impossible to predict microzooplankton biomass and grazing activity only relying on remotely sensed variables. We probably should be conservative on the application of remote sensing to the heterotrophic processes in the ocean (Banse, 2013).

\subsection{Vertical differences of phytoplankton growth and microzooplankton grazing rates}

Comparison of $\mu_{0}$ between surface and DCM waters validates our first hypothesis that light extinction greatly diminishes phytoplankton growth rate at DCM layers. Also consistent with the findings by Landry et al. (2011), we find similar $m$ between surface and DCM layers in winter, and therefore microzooplankton grazed a higher proportion of primary production at the DCM layer in winter. As the two sampling depths in winter were contained within the surface mixed layer at many stations, it is not surprising to find similar microzooplankton community structure and biomass at the two depths in winter (Fig. 3). Although light has been reported to stimulate the grazing activity of some protists (Strom, 2001), this stimulatory effect should not be as strong as the light effect on phytoplankton growth rate.

In contrast, the mean $m$ estimates at the DCM layer were also lower than at the surface in summer shelf and slope waters, and $m / \mu_{0}$ was not different between the two depths. The similar microzooplankton biomass at the two depths suggests that the difference was mainly due to the grazing activity per capita microzooplankton biomass $\left(m / B_{z}\right)$. The reason for the reduced $m / B_{z}$ at the DCM in summer is not very clear, but might be due to a methodological artifact, which was the thermal shock to the plankton community when the incubation was carried out under surface temperatures. In summer, the median temperature difference between surface and DCM layers was about $6^{\circ} \mathrm{C}$, while this difference was negligible in winter. It is possible that this 6-degree temperature difference might impose a thermal shock to the microzooplankton organisms adapted to the DCM layer and artificially lead to a lower $m$ at the DCM in summer. We are currently investigating this problem.

\subsection{Seasonal and spatial patterns of phytoplankton growth and microzooplankton grazing rates}

In contrast to our second hypothesis, we did not observe a lower surface $\mu_{0}$ in summer than in winter. This is somehow unexpected since ambient nutrient concentrations in winter were higher than in summer. The relatively high phytoplankton growth rates $\left(>0.5 \mathrm{~d}^{-1}\right)$ in the basin surface waters of the SCS in the oligotrophic summer could be sustained by grazer nutrient excretion, nitrogen fixation, and episodic nutrient supplies from below the nutricline. If assuming the growth efficiency of microzooplankton is $30 \%$ and the $m / \mu_{0}$ ratio is 0.6 , then microzooplankton excretion can supply $0.6 \times 0.7=42 \%$ of the nutrients required for phytoplankton growth. Considering that there should be higher trophic levels feeding on microzooplankton, the amount of nutrients 

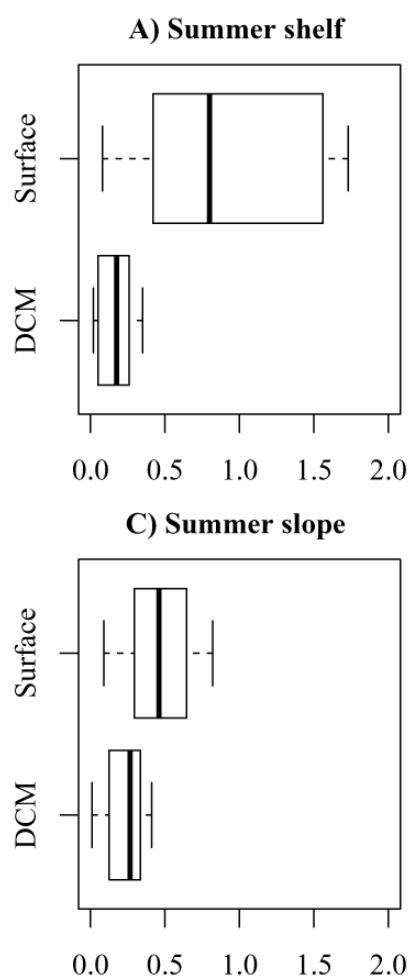

E) Summer basin

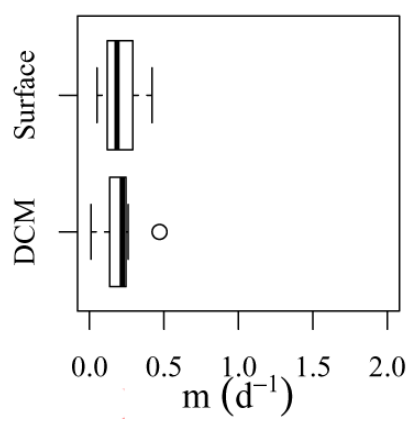

B) Winter shelf

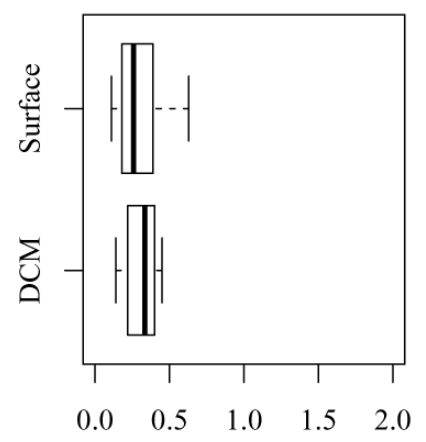

D) Winter slope

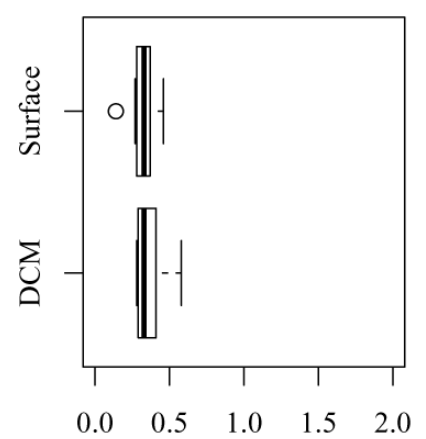

F) Winter basin

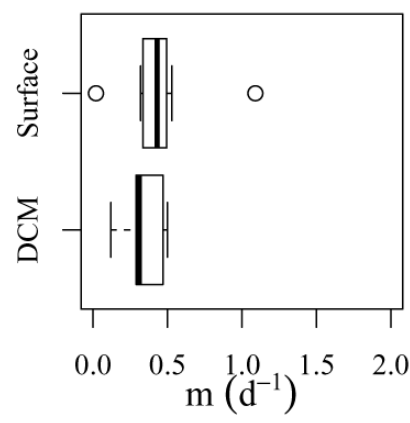

Fig. 5. Box plots of microzooplankton grazing rate $(m)$.

excreted should be higher than the above estimate. The phytoplankton cells in summer might have adapted to the oligotrophic environment by possessing a low-nutrient halfsaturation growth constant. SCS is also well known for the occurrences of internal waves and typhoons (Chen et al., 2009c), which can disturb the stratified water column and periodically inject the nutrients into the euphotic zone from below. The effect of nutrient enrichment on $\mu_{0}$ was small, suggesting that phytoplankton were not experiencing severe nutrient limitation at this time. It is also possible that phytoplankton growth was not at steady state during the time of sampling because $m / \mu_{0}$ was small in surface basin waters in summer. An unexpected typhoon traversed our sampling area during the summer cruise. Certainly, we need more evidence (e.g., measurement of nutrient half-saturation growth constant and the rate of nutrient recycling) to support the above

A) Summer shelf

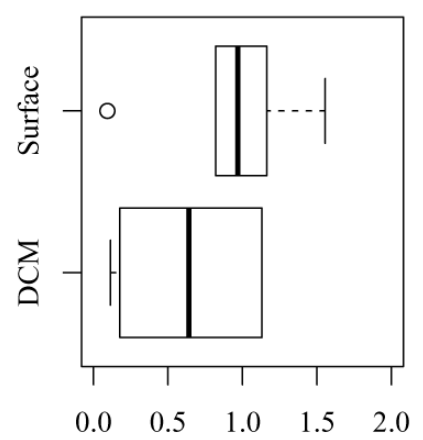

C) Summer slope

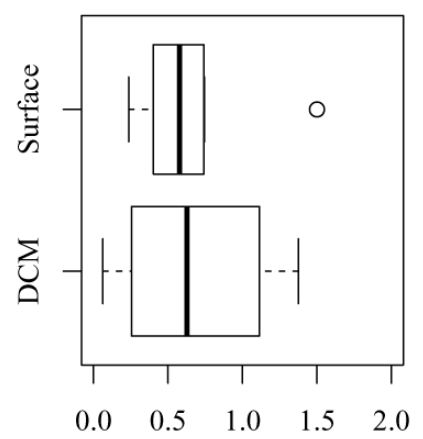

E) Summer basin

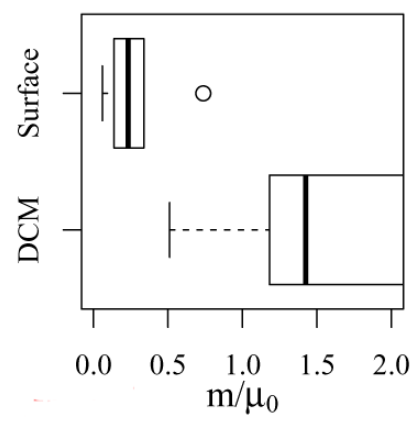

Fig. 6. Box plots of $m / \mu_{0}$.

statements. The high $\mu_{0}$ was also related with the high temperature in summer. The difference of average surface temperature was about 6 degrees between summer and winter. If assuming a $Q_{10}$ of 1.82 (Rose and Caron, 2007), 6 degrees of temperature difference would lead to 1.4 times $\mu_{0}$ difference.

Marra and Barber (2005) and Behrenfeld (2010) suggested that the key factor regulating the variations of phytoplankton biomass in the Arabian Sea and the North Atlantic is likely the changing grazing effect induced by the mixing process, with the bottom-up factors such as nutrients or light being secondary. When vertical mixing occurs, induced either by upwelling, a typhoon, or winter surface cooling, the particle-poor subsurface waters dilute the surface water within the euphotic zone, acting as a natural "dilution" experiment. The grazer biomass and grazing impact on phytoplankton decreases and, as a consequence, the net growth 

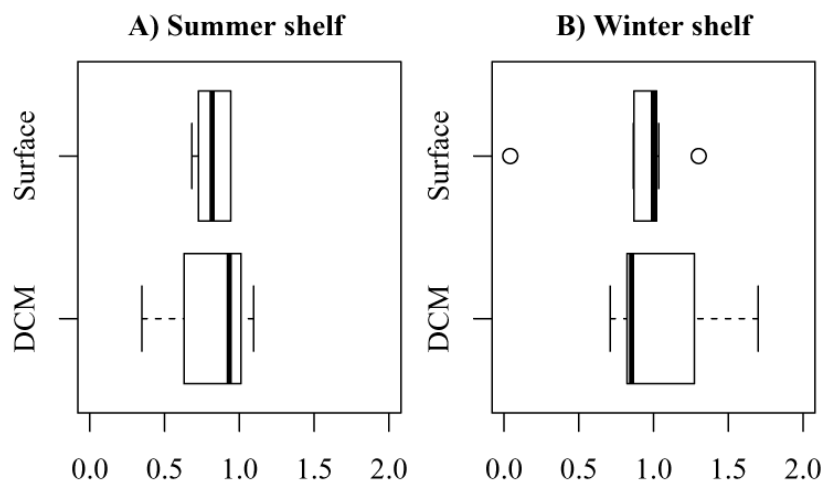

C) Summer slope

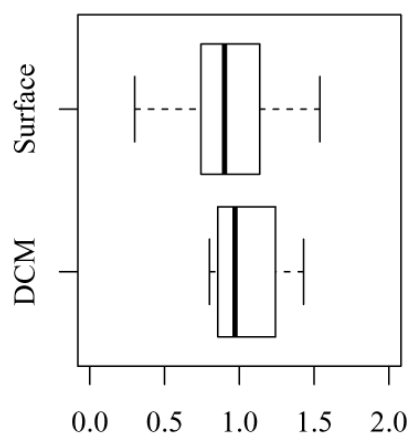

E) Summer basin
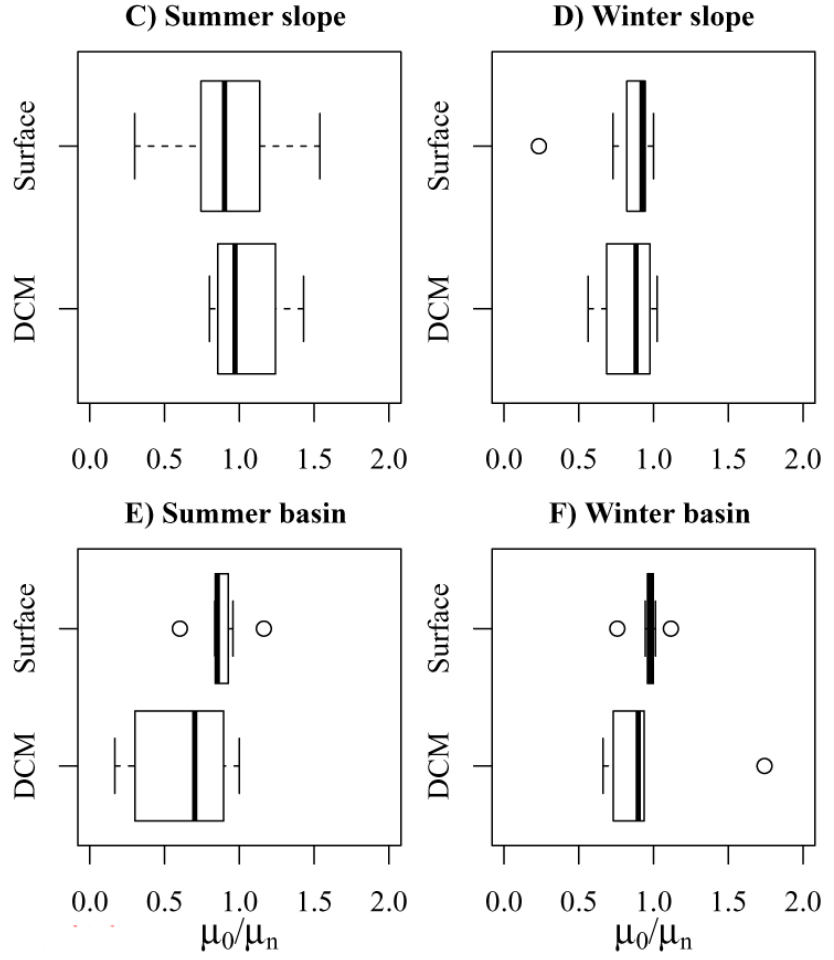

F) Winter basin

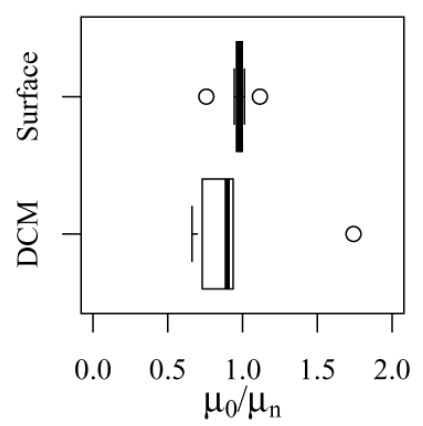

Fig. 7. Box plots of the ratio of $\mu_{0} / \mu_{\mathrm{n}} . \mu_{\mathrm{n}}$ is the nutrient enriched phytoplankton growth rate.

rate of phytoplankton becomes positive and phytoplankton biomass accumulates. It is very likely that we sampled one transitional point during the process when $m$ was decoupled from $\mu_{0}$. We need time series data of $\mu_{0}$ and $m$ to evaluate the relative importance of bottom-up versus top-down factors in affecting changes of phytoplankton biomass.

Contrary to our third hypothesis, we did not observe an increasing trend of $m / \mu_{0}$ from the eutrophic shelf waters to the oligotrophic basin waters in summer surface waters. It may be also caused by the temporal uncoupling of $\mu_{0}$ and $m$ induced by the typhoon as discussed above. It also suggests that some groups of microzooplankton (e.g., heterotrophic dinoflagellates) that are able to feed on prey equal or larger than their own size (Hansen et al., 1994; Sherr and Sherr,
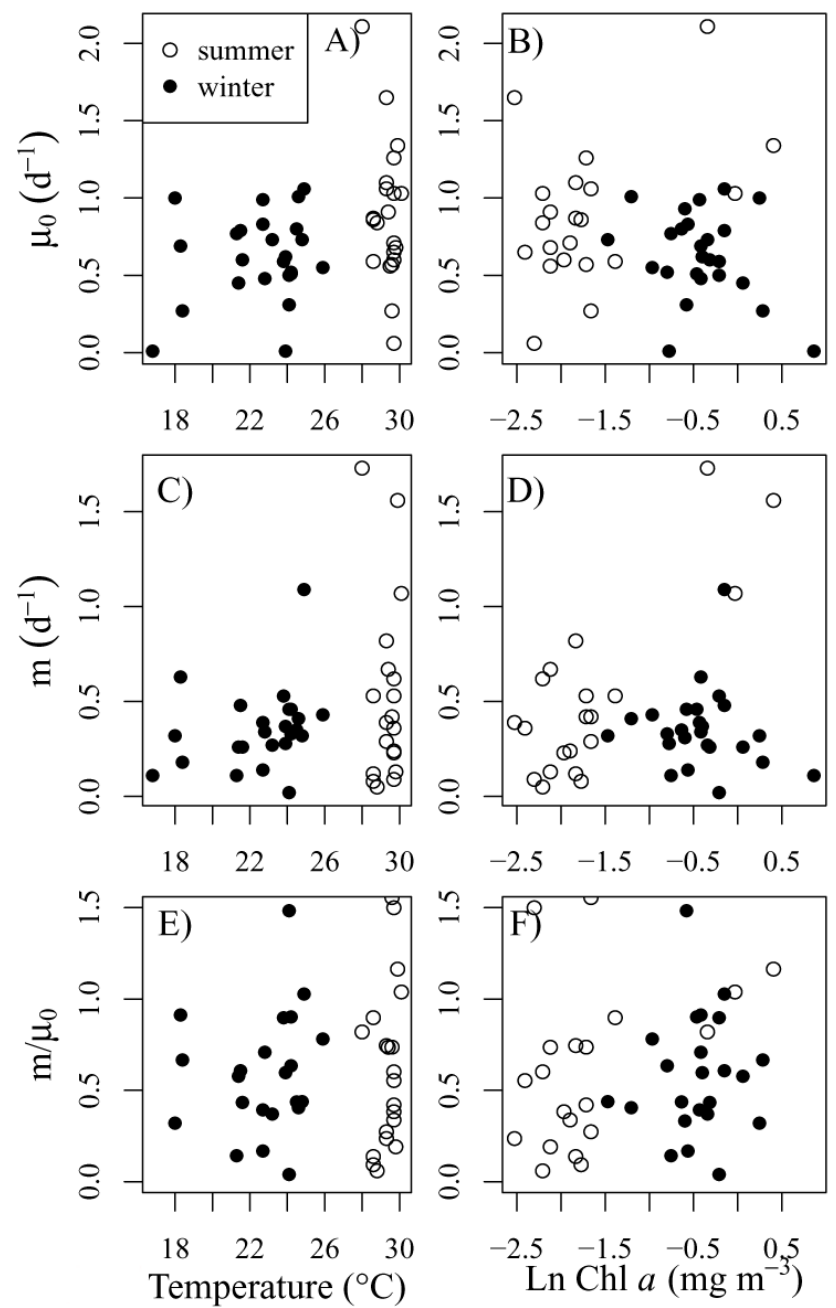

Fig. 8. Relationships of (A, B) $\mu_{0},(\mathbf{C}, \mathbf{D}) m$, and (E, F) $m / \mu_{0}$ with temperature and $\ln \mathrm{Chl} a$ concentrations in surface waters.

2007) can lead to an $m / \mu_{0}$ ratio as high as $1: 1$ in high Chl $a$ waters.

In summary, we have conducted a comprehensive study on microzooplankton herbivory in the northern SCS. Although microzooplankton herbivory is an important loss pathway of primary production, we still do not have sufficient measurements in the ocean particularly in the lower part of the euphotic zone (Landry et al., 2011). As a consequence, there is still no widely accepted theory on microzooplankton grazing that can easily fit field data. Although the global average proportion of primary production grazed by microzooplankton is estimated as from $60 \%$ to $80 \%$, the real ratio of $m / \mu_{0}$ can range from 0 to $100 \%$ with little predictability (Calbet and Landry, 2004; Chen et al., 2012). The real ocean can easily deviate from steady state, disturbed by a variety of physical forcings such as typhoons, mesoscale eddies, etc. Although the coupling between phytoplankton growth and microzooplankton grazing rates is often observed (Murrell et al., 2002), we have shown in this study that the two rates can 
sometimes be decoupled by physical disturbances. While primary production has been mapped at global scales using remote sensing techniques, the estimates of microzooplankton grazing rates are largely scattered. Clearly, plankton ecologists need more accurate measurements in the ocean and also need to develop better theories that can capture the essence of microzooplankton grazing.

\section{Supplementary material related to this article is available online at: http://www.biogeosciences.net/10/ 2775/2013/bg-10-2775-2013-supplement.pdf.}

Acknowledgements. We sincerely thank the captain and crew of the research vessel Dongfanghong-2 and the chief scientists Minhan Dai, Pinghe Cai, and Weidong Zhai for organizing the cruises. We also thank Jianyu Hu, Jia Zhu, and Zhenyu Sun for providing the CTD data and Yong Zhang, Yanping Xu, and Lifang Wang for providing the nutrient data. This study was supported by the National Basic Research Program ("973” Program) of China through Grant 2009CB421203. B. C. was partially supported by the National Science Foundation of China (41106119), Fundamental Research Funds for the Central Universities (2011121007 and 2012121058) of Xiamen University, and Laboratory of Marine Ecosystem and Biogeochemistry (LMEB201102), Second Institute of Oceanography, State Oceanic Administration. H. L. was also supported by Hong Kong University Grants Committee through the Area of Excellence program (AoE/P-04/04) and Hong Kong Research Grant Council General Research Fund grants (661610 and 661911). B. H. was also supported by National Science Foundation of China grants (NSFC 40925018 and 41176112).

Edited by: T. Kobari

\section{References}

Banse, K.: Cell volumes, maximal growth rates of unicellular algae and ciliates, and the role of ciliates in the marine pelagial, Limnol. Oceanogr., 27, 1059-1071, 1982.

Banse, K.: Reflections about chance in my career, and on the top-down regulated world, Ann. Rev. Mar. Sci., 5, 2.1-2.19, doi:10.1146/annurev-marine-121211-172359, 2013.

Behrenfeld, M. J.: Abandoning Sverdrup's Critical Depth Hypothesis on phytoplankton blooms, Ecology, 91, 977-989, 10.1890/091207.1, 2010.

Calbet, A. and Landry, M. R.: Phytoplankton growth, microzooplankton grazing, and carbon cycling in marine systems, Limnol. Oceanogr., 49, 51-57, 2004.

Chen, B. Z. and Liu, H. B.: Relationships between phytoplankton growth and cell size in surface oceans: Interactive effects of temperature, nutrients, and grazing, Limnol. Oceanogr., 55, 965972, 2010.

Chen, B. Z., Liu, H. B., Landry, M. R., Chen, M., Sun, J., Shek, L., Chen, X. H., and Harrison, P. J.: Estuarine nutrient loading affects phytoplankton growth and microzooplankton grazing at two contrasting sites in Hong Kong coastal waters, Mar. Ecol.Prog. Ser., 379, 77-90, 2009a.

Chen, B. Z., Liu, H. B., Landry, M. R., Dai, M. H., Huang, B. Q., and Sun, J.: Close coupling between phytoplankton growth and microzooplankton grazing in the western South China Sea, Limnol. Oceanogr., 54, 1084-1097, 2009b.

Chen, B., Landry, M. R., Huang, B., and Liu, H.: Does warming enhance the effect of microzooplankton grazing on marine phytoplankton in the ocean?, Limnol. Oceanogr., 57, 519-526, doi:10.4319/lo.2012.57.2.0519, 2012.

Chen, Y. L. L. and Chen, H. Y.: Seasonal dynamics of primary and new production in the northern South China Sea: The significance of river discharge and nutrient advection, Deep-Sea Res. I, 53, 971-986, 2006.

Chen, Y. L. L., Chen, H. Y., Jan, S., and Tuo, S. H.: Phytoplankton productivity enhancement and assemblage change in the upstream Kuroshio after typhoons, Mar. Ecol.-Prog. Ser., 385, 111126, 10.3354/meps08053, 2009c.

Edwards, E. S., Burkill, P. H., and Stelfox, C. E.: Zooplankton herbivory in the Arabian Sea during and after the SW monsoon, 1994, Deep Sea Res. II, 46, 843-863, doi:10.1016/s09670645(98)00130-1, 1999.

Frost, B. W. and Franzen, N. C.: Grazing and iron limitation in the control of phytoplankton stock and nutrient concentration - a chemostat analog of the Pacific equatorial upwelling zone, Mar. Ecol.-Prog. Ser., 83, 291-303, 1992.

Gan, J., Cheung, A., Guo, X., and Li, L.: Intensified upwelling over a widened shelf in the northeastern South China Sea, J. Geophys. Res., 114, C09019-C09033, doi:10.1029/2007jc004660, 2009.

Hansen, B., Bjornsen, P. K., and Hansen, P. J.: The size ratio between planktonic predators and their prey, Limnol. Oceanogr., 39, 395-403, 1994.

Huang, B., Xiang, W., Zeng, X., Chiang, K.-P., Tian, H., Hu, J., Lan, W., and Hong, H.: Phytoplankton growth and microzooplankton grazing in a subtropical coastal upwelling system in the Taiwan Strait, Cont. Shelf Res., 31, S48-S56, doi:10.1016/j.csr.2011.02.005, 2011.

Irwin, A. J. and Finkel, Z. V.: Mining a Sea of Data: Deducing the environmental controls of ocean chlorophyll, Plos One, 3, e3836, doi:3810.1371/journal.pone.0003836, 2008.

Landry, M. R. and Hassett, R. P.: Estimating the grazing impact of marine micro-zooplankton, Mar. Biol., 67, 283-288, 1982.

Landry, M. R., Constantinou, J., and Kirshtein, J.: Microzooplankton grazing in the central equatorial Pacific during February and August, 1992, Deep-Sea Res. II, 42, 657-671, 1995.

Landry, M. R., Barber, R. T., Bidigare, R. R., Chai, F., Coale, K. H., Dam, H. G., Lewis, M. R., Lindley, S. T., McCarthy, J. J., Roman, M. R., Stoecker, D. K., Verity, P. G., and White, J. R.: Iron and grazing constraints on primary production in the central equatorial Pacific: An EqPac synthesis, Limnol. Oceanogr., 42, 405-418, 1997.

Landry, M. R., Brown, S. L., Campbell, L., Constantinou, J., and Liu, H. B.: Spatial patterns in phytoplankton growth and microzooplankton grazing in the Arabian Sea during monsoon forcing, Deep-Sea Res. II, 45, 2353-2368, 1998.

Landry, M. R., Constantinou, J., Latasa, M., Brown, S. L., Bidigare, R. R., and Ondrusek, M. E.: Biological response to iron fertilization in the eastern equatorial Pacific (IronEx II), III. Dynamics of phytoplankton growth and microzooplankton grazing, 
Mar. Ecol.-Prog. Ser., 201, 57-72, 2000.

Landry, M. R., Brown, S. L., Neveux, J., Dupouy, C., Blanchot, J., Christensen, S., and Bidigare, R. R.: Phytoplankton growth and microzooplankton grazing in high-nutrient, low-chlorophyll waters of the equatorial Pacific: Community and taxon-specific rate assessments from pigment and flow cytometric analyses, J. Geophys. Res., 108, 8142-8148, 2003.

Landry, M. R., Selph, K. E., and Yang, E. J.: Decoupled phytoplankton growth and microzooplankton grazing in the deep euphotic zone of the eastern equatorial Pacific, Mar. Ecol.-Prog. Ser., 421, 13-24, doi:10.3354/Meps08792, 2011.

Laws, E. A.: Mesozooplankton grazing and primary production: An alternative assessment, Limnol. Oceanogr., 48, 1357-1359, 2003.

Li, W. K. W. and Dickie, P. M.: Monitoring phytoplankton, bacterioplankton, and virioplankton in a coastal inlet (Bedford Basin) by flow cytometry, Cytometry, 44, 236-246, 2001.

Lie, A. A. Y. and Wong, C. K.: Selectivity and grazing impact of microzooplankton on phytoplankton in two subtropical semi-enclosed bays with different chlorophyll concentrations, J. Exp. Mar. Biol. Ecol., 390, 149-159, doi:10.1016/j.jembe.2010.05.001, 2010.

Liu, H. B., Suzuki, K., and Saino, T.: Phytoplankton growth, and microzooplankton grazing in the subarctic Pacific Ocean and the Bering Sea during summer 1999, Deep-Sea Res. I, 49, 363-375, 2002a.

Liu, K. K., Chao, S. Y., Shaw, P. T., Gong, G. C., Chen, C. C., and Tang, T. Y.: Monsoon-forced chlorophyll distribution and primary production in the South China Sea: observations and a numerical study, Deep-Sea Res. I, 49, 1387-1412, 2002 b.

Marra, J. and Barber, R. T.: Primary productivity in the Arabian Sea: A synthesis of JGOFS data, Prog. Oceanogr., 65, 159-175, doi:10.1016/j.pocean.2005.03.004, 2005

Menden-Deuer, S. and Lessard, E. J.: Carbon to volume relationships for dinoflagellates, diatoms, and other protist plankton, Limnol. Oceanogr., 45, 569-579, 2000.

Murrell, M. C., Stanley, R. S., Lores, E. M., DiDonato, G. T., and Flemer, D. A.: Linkage between microzooplankton grazing and phytoplankton growth in a Gulf of Mexico estuary, Estuaries, 25, 19-29, 2002.

Ning, X., Chai, F., Xue, H., Cai, Y., Liu, C., and Shi, J.: Physicalbiological oceanographic coupling influencing phytoplankton and primary production in the South China Sea, J. Geophys. Res., 109, C10005-C10024, doi:10.1029/2004JC002365,, 2004.

Olson, R. J., Zettler, E. R., and DuRand, M. D.: Phytoplankton analysis using flow cytometry, in: Handbook of methods in aquatic microbial ecology, edited by: Kemp, P., Sherr, B. F., Sherr, E. B., and Cole, J. J., Lewis Publishers, New York, 175-186, 1993.

Parsons, T. R., Maita, Y., and Lalli, C. M.: A manual of chemical and biological methods for seawater analysis, Pergamon, New York, 1984
Peters, F.: Prediction of planktonic protistan grazing rates, Limnol. Oceanogr., 39, 195-206, 1994.

Poulin, F. J. and Franks, P. J. S.: Size-structured planktonic ecosystems: constraints, controls and assembly instructions, J. Plankton Res., 32, 1121-1130, doi:10.1093/plankt/fbp145, 2010.

Putt, M. and Stoecker, D. K.: An experimentally determined carbon - volume ratio for marine oligotrichous ciliates from estuarine and coastal waters, Limnol. Oceanogr., 34, 1097-1103, 1989.

Rose, J. M. and Caron, D. A.: Does low temperature constrain the growth rates of heterotrophic protists? Evidence and implications for algal blooms in cold waters, Limnol. Oceanogr., 52, 886-895, 2007.

Sherr, E. B. and Sherr, B. F.: Heterotrophic dinoflagellates: a significant component of microzooplankton biomass and major grazers of diatoms in the sea, Mar. Ecol.-Prog. Ser., 352, 187-197, 2007.

Steinhoff, T., Friedrich, T., Hartman, S. E., Oschlies, A., Wallace, D. W. R., and Körtzinger, A.: Estimating mixed layer nitrate in the North Atlantic Ocean, Biogeosciences, 7, 795-807, doi:10.5194/bg-7-795-2010, 2010.

Strom, S. L., Miller, C. B., and Frost, B. W.: What sets lower limits to phytoplankton stocks in high-nitrate, low-chlorophyll regions of the open ocean?, Mar. Ecol.-Prog. Ser., 193, 19-31, 2000.

Strom, S. L.: Light-aided digestion, grazing and growth in herbivorous protists, Aquat. Microb. Ecol., 23, 253-261, 2001.

Strom, S. L., Macri, E. L., and Olson, M. B.: Microzooplankton grazing in the coastal Gulf of Alaska: Variations in top-down control of phytoplankton, Limnol. Oceanogr., 52, 1480-1494, 2007.

Su, Q., Huang, L., Tan, Y., Xu, R., Li, T., Zhanzhou, X., Zhang, J., and Qiu, D.: Preliminary study of microzooplankton grazing and community composition in the north of South China Sea in Autumn, Mar. Sci. Bull., 9, 43-53, 2007.

Vaulot, D., Courties, C., and Partensky, F.: A simple method to preserve oceanic phytoplankton for flow cytometric analyses, Cytometry, 10, 629-635, 1989.

Welschmeyer, N. A.: Fluorometric analysis of chlorophyll a in the presence of chlorophyll $\mathrm{b}$ and pheopigments, Limnol. Oceanogr., 39, 1985-1992, 1994

Wong, G. T. F., Ku, T. L., Mulholland, M., Tseng, C. M., and Wang, D. P.: The SouthEast Asian time-series study (SEATS) and the biogeochemistry of the South China Sea - An overview, DeepSea Res. II, 54, 1434-1447, 2007.

Zhou, L., Tan, Y., Huang, L., Huang, J., Liu, H., and Lian, $\mathrm{X}$.: Phytoplankton growth and microzooplankton grazing in the continental shelf area of northeastern South China Sea after Typhoon Fengshen, Cont. Shelf Res., 31, 1663-1671, doi:10.1016/j.csr.2011.06.017, 2011

Zubkov, M. V., Burkill, P. H., and Topping, J. N.: Flow cytometric enumeration of DNA-stained oceanic planktonic protists, J. Plankton Res., 29, 79-86, 10.1093/plankt/fbl059, 2006. 